\title{
Diets of Nubian and Granadina Goats Grazing on Arid Rangeland
}

\author{
Miguel Mellado, ${ }^{1}$ Alvaro Rodriguez, ${ }^{2}$ Abundio Olvera, ${ }^{3}$ \\ Jose A. Villarreal, ${ }^{4}$ and Ramiro Lopez ${ }^{5}$
}

Authors are: ${ }^{1}$ Professor of Reproductive Physiology, ${ }^{2}$ Professor of Range Management, ${ }^{3}$ Graduate Student, ${ }^{4}$ Professor of Botany, and ${ }^{5}$ Professor of Animal Nutrition, Department of Nutrition and Feeds, Universidad Autonoma Agraria Antonio Narro, Saltillo, Mexico 25315.

\begin{abstract}
A study was conducted to test the hypothesis that Granadina goats are better suited than Nubian goats to utilize the forage resources of the Chihuahuan desert range. Diet composition (microhistological analysis of fecal samples) and selection relative to availability were investigated among nonpregnant, nonlactating adult Nubian $(n=6)$ and Granadina $(n=6)$ goats grazing rangeland during the rainy period. Granadina goats consumed more $(P<0.05)$ shrubs $(70.6 \%)$ than Nubians $(52.5 \%)$. Atriplex canescens (Pursh.) Nut., Acacia farnesiana (L.) Willd., and Larrea tridentata (DC.) Cov. were more important $(P<0.05)$ forage species for Granadina than for Nubian goats. Forbs consumption was higher $(39.1 \% ; P<0.05)$ for Nubians compared with Granadinas $(27.7 \%)$. Grass consumption was $8.4 \%$ and $1.7 \%$ for Nubian and Granadina goats, respectively $(P<0.01)$. In general, both breeds showed the greatest preference for shrubs and forbs. The diet overlap between breeds was moderate (similarity index $=68$ ). The evidence of this study suggests that in the Chihuahuan desert range, Granadina goats were folivorous (browsers) and rarely grazed in the rainy season, whereas Nubians diversify their diet utilizing a variety of forage classes.
\end{abstract}

\section{Resumen}

En este estudio se probó la hipótesis de que las cabras Granadinas son más eficientes para el aprovechamiento del forraje del desierto Chihuahuense. Se determinó la composición botánica y preferencia de la dieta en cabras Nubias $(n=6)$ y Granadinas $(n=6)$ mantenidas en agostadero en el periodo de lluvias, analizando las muestras de heces con la técnica microhistológica. Las cabras Granadinas consumieron una mayor $(P<0.05)$ cantidad de arbustivas $(70.6 \%)$ comparadas con las cabras Nubias $(52.5 \%)$. Arbustivas como Atriplex canescens, Acacia farnesiana, y Larrea tridentata fueron más $(P>0.05)$ abundantes en la dieta de las cabras Granadinas, en comparación con las Nubias. El consumo de herbáceas por las cabras Nubias fue mayor $(39.1 \% ; P<0.05)$ que las cabra Granadinas $(27.7 \%)$. La utilización de gramíneas fue 5 veces mayor $(P<0.01)$ por las cabras Nubias en comparación con las cabras Granadinas. En general, las cabras de ambas razas mostraron mayor preferencia por arbustivas y herbáceas. El traslape de plantas en las dietas de las cabras fue moderado (índice de similaridad = 68). Las evidencias de este estudio sugieren que, con relativa abundancia de forraje, las cabras Granadinas se concentran en la utilización de las arbustivas y evitan las gramíneas, mientras que las cabras Nubias diversifican su dieta utilizando una mayor proporción de otras clases de forrajes.

Key Words: Botanical composition, diet preference, grazing pattern, goat breeds, microhistological analysis

\section{Introduction}

Knowledge of the foraging behavior and associated digestive physiology of herbivores can be used to implement practical decisions in land use management. With this information, it would be possible to decide which breed of animal is best suited to exploit a particular plant community. Studies with dairy (NjokaNjiru et al 2001) and native (Odo et al 2001) goats in tropical environments indicate marked differences in grazing behavior and food choice among breeds of goats. Likewise, comparative studies between Angora and Spanish goats indicate that Spanish goats eat less grass and forbs than Angora goats (Davis et al 1974; Bryant et al 1979; Warren et al 1984). Different sheep breeds also choose different diets in the same grazing environments (Du Toit and Blom 1995; Osoro et al

Correspondence: Dr Miguel Mellado, UAAAN, Department Nutrición y Alimentos, Saltillo, Coah, Mexico 25315, México. Email: mmellbosq@yahoo.com

Manuscript received 31 March 2003; manuscript accepted 22 April 2004.
1999; Ashutosh et al 2002). There is, however, little information on dietary choice differences between breeds of goats in arid environments.

The objective of this study was to test the hypothesis that Granadina goats are better suited than Nubian goats to utilize the forage resources of the Chihuahuan desert range. This is based on the assumption that in the arid zones of Mexico, Granadina goats possess a higher grazing proficiency than Nubian goats because of adaptation to this food-limited ecosystem.

\section{Materials and Methods}

\section{Study Site Description}

The study was conducted on rangelands in the Chihuahuan desert biome of northeast Mexico $\left(101^{\circ} 20^{\prime} \mathrm{W}, 25^{\circ} 30^{\prime} \mathrm{N}\right)$. Precipitation averaged $32.2 \mathrm{~cm}$ from 1990 to 1999 , with $75 \%$ falling from June to October. July is normally the wettest month with rainfall averaging $5.8 \mathrm{~cm}$. Average maximum daily temperatures range from $28^{\circ} \mathrm{C}$ in January to $37.2^{\circ} \mathrm{C}$ in July. Average 
minimum daily temperatures range from $-0.7^{\circ} \mathrm{C}$ in January to $12.3^{\circ} \mathrm{C}$ in July. Elevation varies from 1600 to $1800 \mathrm{~m}$ with level or gently rolling hills. Soils of the study site are mainly silty underlain by calcium carbonate hardpan at depths varying from a few centimeters to more than $1 \mathrm{~m}$.

The most commonly encountered shrub species was creosote bush (Larrea tridentata (DC.) Cov.). Other shrubs commonly found were lechuguilla (Agave lechuguilla Torr.), huisache (Acacia farnesiana (L.) Willd.), and tarbush (Flourensia cernua D.C.). The succulent prickly pear (Opuntia rastrera Weber.) was also common. Primary grasses included sideoats grama (Bouteloua curtipendula (Michx.) Torr.) and Arizona three-awn (Aristida arizonica Vasey). The most commonly encountered forb species were globe-mallow (Sphaeralcea angustifolia (Cav.) D. Don.) and silver-leaf nightshade (Solanum elaeagnifolium Cav.). Historically, this pasture has been heavily stocked (approximately 1.5 ha per goat) and continuously grazed exclusively by large flocks of goats.

\section{Animals and Management}

Six Granadina and 6 Nubian does were used in the study. Granadina does had a mean live weight of $39.2 \mathrm{~kg}(\mathrm{SD}=4.8)$ and a mean height to withers of $62 \mathrm{~cm}(\mathrm{SD}=3.1)$, and Nubian goats had a mean live weight of $47 \mathrm{~kg}(\mathrm{SD}=5.2)$ and a mean height to withers of $69 \mathrm{~cm}(\mathrm{SD}=2.7)$. All goats were adult nonpregnant nonlactating, which were born and reared in a commercial flock of goats $(n=250)$ of undefined genotype, typical of the farming systems of the arid zones of northern Mexico. Given that early life experience for the 2 breeds was the same, it was assumed that tactical decisions about dietary choices was driven by the search of an adequate level of nutrients to meet the maintenance demands. Granadina goats in Mexico are small-framed agile animals well adapted to the arid and semiarid zones of Mexico. These animals have been raised in these harsh environments during 4 centuries without a selection effort for milk or meat production. Nubian goats, on the other hand, were introduced in these resource-poor pastoral systems approximately 30 years ago.

Goats grazed on open range ( $1050 \mathrm{ha}$ ) year round driven by a herdsman for $8 \mathrm{~h}^{\circ} \mathrm{d}^{-1}$ (from 1000 to 1800 hours). Grazing constraints related to diet selection were considered negligible because goats were taken to different grazing sites every day and animals walked long distances daily (approximately $3 \mathrm{~km}$ from the pen). Decisions on where to feed, distance between foraging sites, and length of grazing were based on forage quality and quantity in the pasture. These grazing patterns allowed free choice among existing vegetative species. Stocking rates were 1.5 ha per goat, which was above the carrying capacity of this rangeland.

\section{Diet Analysis}

For assessment of the diet selected, fecal samples (approximately 10 pellets per animal) were collected from the rectum of goats during October 2001 (wet season). During the sampling period, 5 samples were collected from each goat on 5 successive days. The samples were dried at $50^{\circ} \mathrm{C}$ in an oven for 72 hours. Feces were then ground in a Willey mill with a $1-\mathrm{mm}$ mesh screen. The 5 samples were bulked, thoroughly mixed, and a subsample was taken from the mixture. Botanical composition of goat diets was determined using the microhistological technique described by Sparks and Malechek (1968). Five slides from each sample were analyzed with a compound, phasecontrast microscope until 100 fragments were identified. Unidentified forage fragments were approximately $1 \%$. Preference values were based on the following equation described by Taylor et al (1980):

$$
\text { Selection index }=\frac{(\% \text { in diet }-\% \text { ground cover })}{(\% \text { in diet }+\% \text { ground cover })} \times 10 \text {. }
$$

Ratings of $+10,-10$, and -1 to +1 indicate maximum preference, minimum preference, and selection in proportion to availability, respectively. Similarity of diets was calculated using Kulczynski’s similarity index (Oosting 1956).

\section{Vegetation Analysis}

Vegetation (foliage) cover in the pasture was determined at the end of the rainy season (October 2001) by measuring all vegetation encountered in five $500-\mathrm{m}$ permanent transects placed in representative sites over the study area. In each transect the intercept of each plant species was summed and divided by the total length of the transect to obtain the percent cover (Canfield 1942) per sampling unit (transect).

\section{Statistical Analysis}

Prior to statistical analysis, the numbers of epidermal fragments of each species were converted to percentages and transformed to arcsin (angular; Steel and Torrie 1980) to normalize their distribution. The individual animal was the sampling unit ( $n=6$ per breed). Botanical components of feces between animal genotypes were analyzed using a 1-way ANOVA (SAS 1990), with breed as the main effect and does within breed as the error term. It was assumed that the restriction imposed on the randomization did not affect responses. Statistical inference is limited to the study site used in this research. Significant differences in selection indices were assessed using the KruskalWallis test (SAS 1990).

\section{Results}

\section{Vegetation Cover}

Browse species ( $75 \%$ of the total ground cover) provided the major portion of available forage for goats during the trial (Fig. 1). Grasses comprised less than $7 \%$ of the total vegetation cover.

\section{Breed Effect}

Shrubs were 18 percentage units greater $(P<0.05)$ in Granadina goat diets compared with Nubian goats and accounted for over half of the diet in the rainy season (Table 1). Parthenium incanum was the most utilized shrub by both breeds of goats. Nubian goats consumed more $(P<0.10)$ Agave lechuguilla than Granadina goats. On the other hand, Granadina goats consumed almost 3 times more $(P<0.01)$ Larrea tridentata and 2 times more $(P<0.01)$ Atriplex canescens than Nubian goats. During the rainy season, Opuntias were detected in low amounts (around $8 \%$ ) in the diets of both breeds of goats. 


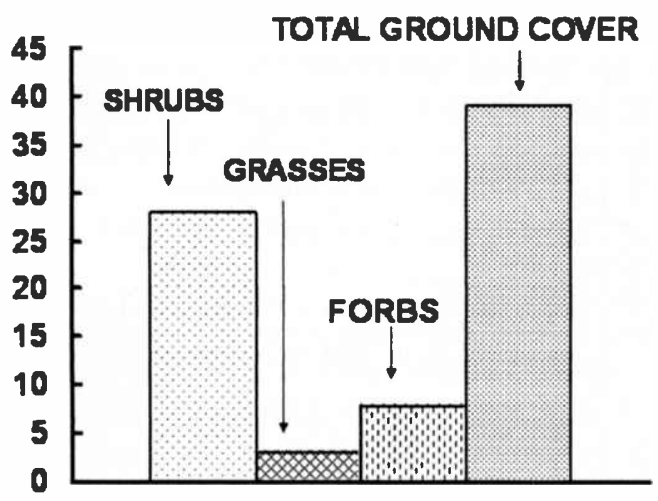

Figure 1. Aerial cover of shrubs, forbs, and grasses on the study site during the rainy season.

Mimosa biuncifera contributed little to Granadina goat diets, whereas Nubian goats completely avoided it.

Forbs, which were abundant during the sampling season, were $39 \%$ of the Nubian goat diets compared with $27 \%$ of Granadina goat diets (Table 1; $P<0.05$ ). Croton dioicus, Solanum elaeagnifolium, and Sphaeralcea angustifolia were important forbs in the diet of both breeds of goats (Table 1). Nubian goat diets contained 5 times more $(P<0.01)$ grasses as that of Granadina goats. Bouteloua curtipendula, the only appreciable grass in the Nubian goat diets, was not detected in Granadina goat diets.

Dietary preferences of Nubian and Granadina for specific plant species differed between the 2 breeds of goats (Table 2). Nubian goats showed a greater $(P<0.10)$ preference for Agave lechuguilla compared with Granadina goats, whereas Granadina goats showed a greater $(P<0.05)$ preference for Acacia farnesiana and Larrea tridentata compared with Nubian goats. In general, for both groups of goats preference ranking for grasses was lower than that from shrubs and forbs. Dietary overlap between breeds in the rainy season was moderate (similarity index $=68$ ).

\section{Discussion}

The results show clear evidence of a difference between Nubian and Granadina goats in diet selection during the growing season. Contrary to expectations, browse was a more important forage source for Granadina goats than Nubian goats during the wet period, which means that in goats, larger body size not necessarily confers advantages in situations where browse is an abundant food resource. Percentage of Agave lechuguilla in Nubian goat diets was over twice that of the Granadina goats, which implies that mechanical defenses of this plant did not deter Nubian goats from using this plant. Goat preference for Agave lechuguilla, particularly during the dry season, has also been reported in other studies (Mellado et al 1991). On the other hand, Acacia farnesiana, the leguminous tree with the greatest nutrient content and lesser levels of tannins in this ecosystem (Ramirez et al 1999), was used in greater amount by Granadina goats compared with Nubians. Also, Atriplex canescens, another high-quality forage (Garza and Fulbright 1988) was a larger portion of Granadina goat diets than of Nubian goat diets. Larrea tridentata, a shrub that
Table 1. Diet composition (\%) of adult nonproductive Nubian and Granadina goats grazing on a Chihuahuan desert rangeland in the rainy season in northeastern Mexico (Values are means \pm SD). ${ }^{1}$

\begin{tabular}{|c|c|c|}
\hline Species & Nubian & Granadina \\
\hline Acacia farnesiana & $2.6 \pm 1.9^{a}$ & $8.3 \pm 2.9^{b}$ \\
\hline Agave lechuguilla & $3.9 \pm 2.3^{x}$ & $1.5 \pm 1.3^{y}$ \\
\hline Agave striata & $3.7 \pm 2.1$ & $2.6 \pm 1.7$ \\
\hline Atriplex canescens & $2.6 \pm 1.8^{\mathrm{a}}$ & $5.8 \pm 0.5^{b}$ \\
\hline Cowania plicata & $6.9 \pm 2.2$ & $9.4 \pm 4.6$ \\
\hline Dasylirion palmeri & $4.5 \pm 2.7$ & $3.5 \pm 1.6$ \\
\hline Larrea tridentata & $3.0 \pm 1.6^{A}$ & $8.6 \pm 1.4^{B}$ \\
\hline Mimosa biuncifera & - & $3.4 \pm 1.8$ \\
\hline Nolina cespitifera & $1.0 \pm 1.3^{x}$ & $3.2 \pm 2.1^{y}$ \\
\hline Opuntia imbricata & $1.9 \pm 1.2$ & $3.5 \pm 2.9$ \\
\hline Parthenium incanum & $9.1 \pm 6.8$ & $10.1 \pm 3.0$ \\
\hline Other shrubs & 13.3 & 10.7 \\
\hline Total shrubs & $52.5 \pm 37.2^{\mathrm{a}}$ & $70.6 \pm 32.5^{5}$ \\
\hline Croton dioicus & $7.3 \pm 2.4$ & $9.6 \pm 3.4$ \\
\hline Sida abutifolia & $3.3 \pm 1.4$ & - \\
\hline Solanum elaeagnifolium & $13.9 \pm 5.2^{A}$ & $5.2 \pm 2.7^{B}$ \\
\hline Sphaeralcea angustifolia & $11.9 \pm 3.3^{\mathrm{a}}$ & $9.0 \pm 2.6^{b}$ \\
\hline Other forbs & 2.7 & 3.9 \\
\hline Total forbs & $39.1 \pm 14.4^{a}$ & $27.7 \pm 12.3^{t}$ \\
\hline Bouteloua curtipendula & $2.6 \pm 1.8$ & - \\
\hline Bromus catharticus & $2.4 \pm 2.6$ & - \\
\hline Other grasses & 3.4 & 1.7 \\
\hline Total grasses & $8.4 \pm 5.8^{A}$ & $1.7 \pm 1.2^{B}$ \\
\hline
\end{tabular}

${ }^{1}$ Values in the same line with different superscript differ $\left({ }^{x, y} P<0.10 ;{ }^{a, b} P<0.05\right.$; $A, B P<0.01$ ). Empty cells indicate that plants were not detected in tecal samples.

possesses a complex array of allelochemicals (Hyder et al 2002) and normally is an important component only during the dry season (Mellado et al 2003), was over twice as high in diets of Granadina goats compared with Nubian goats. High levels of this plant in the Granadina goat diets were not caused by a lack of alternative forage. Unlike Nubian goats, Granadina goats appear to have developed mechanisms to detoxify chemically defended shrubs common to this region. Theoretically, the capacity to tolerate phytotoxins can be acquired during development, modulated during adulthood, or genetically fixed (Launchbaugh et al 1999). The large selection of Larrea tridentata by Granadina goats when there was not a shortage of forage suggests that genetic factors underlay Granadina goats' adaptation to Larrea tridentata secondary metabolites. Development of tolerance to Larrea tridentata has been reported in other herbivores (Mangione et al 2000), and inherent differences between species in metabolic detoxification pathways of other plant species have been documented (Wachenheim et al 1992). Feeding on this less preferred but more abundant shrub may have a significant impact on longterm survival and reproductive success in Granadina goats.

The substantially higher consumption of shrubs by Granadina compared with Nubian goats merits discussion. Granadina goats apparently maximized diet quality by combining highly nutritious shrubs with browse rich in allelochemicals, and the utilization of total shrubs could be increased without the risk of toxicity for this breed. This foraging strategy to 
Table 2. Influence of genotype of goats on forage preferences in an arid rangeland of northern Mexico in the rainy season. Values are selection indexes (mean $\pm \mathrm{SD}$ ) of main species utilized by goats. ${ }^{1}$

\begin{tabular}{lcc}
\hline Species & Nubian & Granadina \\
\hline Acacia farnesiana & $5.9 \pm 1.7^{\mathrm{a}}$ & $8.8 \pm 0.6^{\mathrm{b}}$ \\
Agave lechuguilla & $5.8 \pm 0.7^{\mathrm{x}}$ & $3.2 \pm 3.1^{\mathrm{y}}$ \\
Agave striata & $7.3 \pm 1.3$ & $8.0 \pm 1.1$ \\
Atriplex canescens & $6.6 \pm 1.4^{\mathrm{x}}$ & $8.1 \pm 0.4^{\mathrm{y}}$ \\
Cowania plicata & $8.0 \pm 0.9$ & $8.9 \pm 0.8$ \\
Dasylirion palmerii & $9.5 \pm 0.1$ & $9.2 \pm 0.2$ \\
Larrea tridentata & $-2.2 \pm 3.7^{\mathrm{a}}$ & $1.5 \pm 1.6^{\mathrm{b}}$ \\
Mimosa biuncifera & - & $6.5 \pm 1.1$ \\
Nolina cespitifera & $8.7 \pm 0.8$ & $9.7 \pm 1.3$ \\
Opuntia imbricata & $8.8 \pm 0.5$ & $9.5 \pm 1.0$ \\
Parthenium incanum & $6.9 \pm 2.0$ & $7.0 \pm 1.4$ \\
Sida abutifolia & $7.8 \pm 0.7$ & - \\
Solanum elaeagnifolium & $8.5 \pm 0.9^{\mathrm{a}}$ & $6.2 \pm 1.0^{\mathrm{b}}$ \\
Sphaeraalcea angustifolia & $8.7 \pm 0.9$ & $7.9 \pm 0.4$ \\
Bouteloua curtipendula & $5.1 \pm 1.1$ & - \\
Bromus catharticus & $5.8 \pm 1.4$ & - \\
\hline
\end{tabular}

IValues in the same line with different superscript differ $\left({ }^{x, y} p<0.10\right.$; $\left.{ }^{a, b} p<0.05\right)$. Empty cells indicate that plants were not detected in fecal samples.

avoid toxicity has been documented previously in goats (Duncan and Young 2002). An additional strategy of Granadina goats to heavily depend on shrubs could be a reduction in problems caused by internal parasites infections due to direct inhibitory effects of condensed tannins on parasite larvae (Min et al 2003) and the reduction of ingestion of infective larvae due to the taller plant morphology (Barry et al 2002).

Nubian goats consumed a greater amount of forbs than did Granadina goats during the rainy season. For both breeds, most of the herbaceous plants present in the study site were consumed, with no evidence of any species of weed being avoided. These results reaffirm that in the Chihuahuan desert, forbs are a staple food for goats during the growing season (Mellado et al 1991, 2003).

The results from this study are supported generally by the findings of others relative to the effect of breed of small ruminants on diet botanical composition. Odo et al (2001) reported significant differences in time spent eating and food choice among 3 local breeds of goats of West Africa. In a tropical environment, both during the wet and dry seasons, Toggenburgs spent more time than Saanens feeding on natural vegetation (NjokaNjiru et al 2001). In sheep, differences between breeds have been observed in voluntary forage intake (Vulich et al 1990; Osoro et al 1999); diet selection (Warren et al 1984; Revesado et al 1994; Toil 1998; Osoro et al 1999); rumen outflow rate (Lourenco et al 2000); and ruminal degradation rate (Ranilla et al 1997).

Differences in anatomy and physiology between Nubian and Granadina goats could also account for dissimilarities in food selection. Granadina goats weighed less than $40 \mathrm{~kg}$, a size for which unselective feeding apparently ceased to be a viable strategy, because small animals require more energy per unit body weight (Demment and Van Soest 1985). Nubian goats, on the other hand, probably have a greater capacity to process and survive on medium- to high-quality forages with lower fermentation rate, since metabolic needs scale with body weight (BW) as $\mathrm{BW}^{0.75}$ and gut contents scale isometrically with $\mathrm{BW}$. Additionally, in small ruminants bite size and bite weight (Demment et al 1995; Osoro et al 1999) as well as ability to harvest herbage (Illius and Gordon 1987) are related to animal size.

When forage was relatively abundant, goat diets did not conform closely to the proportions of food available, which indicates that goats of both breeds behave highly selectively when foraging in this plant community. The higher selectivity of Atriplex canescens and Acacia farnesiana by Granadina goats, compared with Nubians, can be explained on the basis of nutrient maximization of the smaller animals, whereas physiological adaptations to the secondary compounds of Larrea tridentata seems to explain the lower aversion of Granadina goats to this shrub compared with Nubian goats.

\section{Conclusions}

Our data suggest that in the Chihuahuan desert range, unselective feeding was not a viable strategy for Granadina goats, which concentrated on tender-leaved shrubs and ignored grasses. However, Granadina goats broadened their diet to include substantial amounts of plants with high phytotoxins, such as Larrea tridentata, which indicate that Granadina goats were more efficient than Nubian goats at using plants with high antiherbivory chemicals. Nubians' lesser shrub intake, greater forb consumption, and higher grass utilization than Granadinas are possibly due to the goats' bulk and less selective foraging pattern. In terms of management, increased utilization of shrubs by Granadinan compared with Nubian goats may indicate that this breed could be more beneficial in reversing shrub encroachment than other breeds. The greater inclusion of Larrea tridentata in their diets may be especially beneficial. Additionally, goat production in arid zones may be favored by the utilization of Granadina goats, because they are less dependent on herbaceous plants, which are short-lived and unpredictable. Moreover, Granadina goats virtually ignored grasses during humid conditions, which implies a reduced overlap in resource utilization with bovines in this plant community.

\section{Literature Cited}

Ashutosh, O.P., G. Dhanda, and G. Singh. 2002. Changes in grazing behaviour of native and crossbred sheep in different seasons under semi-arid conditions. Tropical Animal Health and Production 34:399-404.

BarRy, T. N., S. O. Hoskin, AND P. R. WILSON. 2002. Novel forages for growth and health in farmed deer. New Zealand Veterinary Journal 50:244-251.

Bryant, F. C., M. M. Kothmann, and L. B. Merrill. 1979. Diets of sheep, Angora goats, Spanish goats and white-tailed deer under excellent range conditions. Journal of Range Management 32:412-417.

CANFIELD, R. H. 1942. Application of the line interception method of sampling range vegetation. Journal of Forestry 39:388-394.

Davis, G. G., E. E. Lawrance, and C. W. Cook. 1974. Control of gambleoak by goats. Journal of Range Management 28:216-218.

Demment, M. W., J. L. Peyraud, and E. A. Laca. 1995. Herbage intake at grazing: a modeling approach. In: M. Journet, E. Grenet, M.-H. Farce, M. Theriez, and V. Demarquilly [eds.]. Recent developments in the nutrition of herbivores. 
Proceedings of the IVth International Symposium on the Nutrition of Herbivores. Paris, France: INRA. p 121-141.

Demment, M. W., and P. J. Van Soest. 1985. A nutritional explanation for bodysize patterns of ruminants and nonruminants herbivores. American Naturalist 125:641-672.

Du Tolt, P. C. V. 1998. A comparison of the diets selected by Merino and Doper sheep on three range types of the Karoo, South Africa. Archives of Zootechnie 47:21-32.

Du Tolt, P. C. V., AND C. D. BLom. 1995. Diet selection by sheep and goats in the Noorsveld. African Journal of Range Forage Science 12:27-37.

Duncan, A. J., and S. A. Young. 2002. Can goats learn about foods through conditioned food aversions and preferences when multiple food options are simultaneously available? Journal of Animal Science 80:2091-2098.

GarzA, A., And T. E. Fulbright. 1988. Comparative chemical composition of armed saltbush and fourwing saltbush. Journal of Range Management 41:401-403.

Hyder, P. W., E. L. Fredrickson, R. E. Estell, M. Tellez, and R. P. Gibbens. 2002. Distribution and concentration of total phenolics, condensed tannins, and nordihydroguaiaretic acid (NDGA) in creosotebush (Larrea tridentata). Biochemical Systematics and Ecology 30:905-912.

ILLIUS, A. W., AND I. J. GoRdon. 1987. The allometry of food intake in grazing ruminants. Journal of Animal Ecology 56:989-999.

Launchbaugh, K. L., J. W. Walker, and C. A. Taylor. 1999. Foraging behavior: experience or inheritance? In: K. L. Launchbaugh, J. C. Mosley, and K. D. Sanders [eds]. Grazing behavior of livestock and wildlife. Idaho Forest, Wildlife and Range Experimental Station Bulletin No. 70. p 28-35.

Lourenco, A. L. G., A. A. Diasda Silva, A. J. M. FonsecA, And J. T. Azevedo. 2000. Effect of live weight, maturity and genotype of sheep fed a hay-based diet, on intake, digestion and live weight gain. Livestock Production Science 63:291-296.

Mangione, A. M., M. D. Dearing, and W. H. Karasov. 2000. Interpopulation differences in tolerance to creosote bush resin in desert woodrats (Neotoma lepida). Ecology 81:2067-2076.

Mellado, M., R. H. Foote, A. Rodriguez, and P. Zarate. 1991. Botanical composition and nutrient content of diets selected by goats grazing on desert grassland in northern Mexico. Small Ruminant Research 6:141-150.

Mellado, M., R. Valdez, L. M. Lafa, and R. Lopez. 2003. Stocking rate effects on goats: a research observation. Journal of Range Management 56:167-173.

Min, B. R., T. N. BarRy, G. T. AtTwood, and W. C. McNabB. 2003. The effects of condensed tannins on the nutrition and health of ruminants fed fresh temperate forages: a review. Animal Feed Science and Technology 106:3-19.

Nuokanjiru, E. N., J. M. Ojango, M. K. Ambula, and C. M. Noirangu. 2001. Grazing behaviour of Saanen and Toggenburg goats in sub-humid tropical conditions of Kenya. Asian-Australasian Journal of Animal Sciences 14:951-955.

Odo, B. I., F. U. OMEJE, And J. N. OKwor. 2001. Forage species availability, food preference and grazing behaviour of goats in Southeastern Nigeria. Small Ruminant Research 42:163-168.

Oosting, H. J. 1956. The study of plant communities. San Francisco, CA: W. H. Freeman and Co. $440 \mathrm{p}$.

Osoro, K., M. Olivan, R. Celaya, and A. Martinez. 1999. Effect of genotype on the performance and intake characteristics of sheep grazing contrasting hill vegetation communities. Animal Science 69:419-426.

Ramirez, R. G., H. Gonzalez-Rodriguez, M. V. Gomez-Meza, and M. A. Perez-Rodriguez. 1999. Feed value of foliage from Acacia rigidùla, Acacia berlandieri and Acacia farnesiana. Journal of Applied Animal Research 16:23-32.

Ranilla, M. J. M. D. Carro, C. Valdes, F. J. Giradles, and S. Lopez. 1997. A comparative study of ruminal activity in Churra and Merino sheep offered alfalfa hay. Animal Science 65:121-128.

Revesado, P. R., A. R. Mantecon, P. Frutos, and J. S. González. 1994. Comparative studies of diet selection by Churra and Merino genotypes grazing on a hill shrub community. In: T. L. J. Lawrence, D. S. Parker, and P. Rowlinson [eds.]. Livestock production and land use in hills and uplands. British Society of Animal Production Occasional publication No. 18. p 111-112.

SAS. 1990. SAS procedure users guide version 6. 3rd ed. Cary, NC: SAS Institute Inc.

SpaRKS, D. L., AND J. C. MaLeCHEK. 1968. Estimating percentage dry weight in diets using a microscopic technique. Journal of Range Management 21:264-265.

Steel, R. G., And J. H. Torrie. 1980. Principles and procedures of statistics. 2nd ed. New York, NY: McGraw-Hill Book Co. 663 p.

Taylor, C. A., M. M. Kothmann, L. B. Merrill, and D. Elledge. 1980. Diet selection by cattle under high-intensity, low-frequency, short duration, and Merril grazing systems. Journal of Range Management 33:428-434.

Vulich, S. A., J. P. Hanrahan, and E. G. O'Riordan. 1990. Variation of intake at pasture: differences among breeds of sheep of different mature size. Proceedings IV World Congress on Genetics Applied to Livestock Production. Edinburgh, Scotland. 15:57-60.

Wachenheim, D. E., L. L. Blythe, and A. M. Craig. 1992. Characterization of rumen bacterial pyrrolizidine alkaloid biotransformation in ruminants of various species. Veterinary and Human Toxicology 34:513-517.

Warren, L. E., D. N. Ueckert, and J. M. Shelton. 1984. Comparative diets of Rambouillet, Barbado, and Karakul sheep and Spanish and Angora goats. Journal of Range Management 37:172-180. 